\title{
ОНТОЛОШКА ИКОНИЧНОСТ ЦАРСТВА БОЖИЈЕГ
}

\author{
Дарко Стојановић* \\ Висока школа - Академија СПЦ за уметности \\ и консервацију, Београд
}

Сажетак: Уметност се преображава у логосни славослов не психолошким преображајем, већ онтолошким, односно већ створено постаје уистину ново, једном стварношћу која је заиста ново. Есхатолошка чињеница омогућава човеку да обухвати сву сложеност света, те га на један истински и посве слободан начин трансформише у један нови свет. Тада једна реалност која га запьускује постаје кроз предмет чисто словесног созериања очигледна непосредност. Опит есхатона односно опит искуства које произилази из тог опита прожима се са искуством естетским, пружајући и дајући човеку искуство очигледне стварности. Али то не значи да је лепота својствена само Будућем веку, она је својствена и овом веку уколико човек као тварна ипостас, своју творећу природу изражава не само као средство приближавања Богу, већ као са-стваралаштво са својим Творием. Тачније тада искуство очигледне стварности постаје чињеница преображења творевине.

Кључне речи: онтологија, икона, Царство Божије, православље, ирквена уметност.

\section{Увод}

Целокупан процес развоја теологије иконе (грч: H $\theta \varepsilon o \lambda o \gamma i \alpha$ $\tau \eta \varsigma$ Elкóvos) у историји православне уметности се дуго време

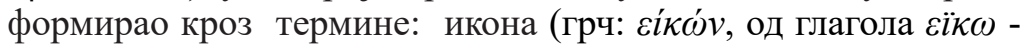

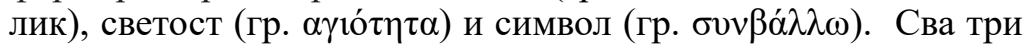
појма теологије иконе свој извор и смисао налазе у непролазном Царству Божијем. Икона је своју примену у теологији добила на нивоу есхатологије, са јасним нагласком да је икона оно што се ишчекује. Сам појам светости у теологији подразумева онтолошко-сотириолошку димензију. Символ - символизам у теологији своју форму пројављује у реалној стварности, упућује на последњу реалност - Царство Божије. Посматрајући

*ел.пошта: darkostoja@gmail.com 
из црквеног угла можемо видети да сва три појма нису ништа друго него саборно, заједничко и молитвено дело које се ослања на догађаје који су се догодили у прошлости и сведоче о догађајима који ће се тек догодити у будућности - Царству Божијем.

Црквена уметност се тиче самог бића Цркве, њеног предања утемељеног на литургијском догађају. Она је једна врста сликарства, предавања, проповедања, певања,... у бојама, словима и нотама ствараоца. Визионарско и стваралачко исказивање уметника је уметнички аспект без кога се не може замислити сведочење историјских и есхатолошких догађаја у нашим храмовима. Уметност укључује ширину и слободу уметника кроз креативност и неукалупљеност. Уметност није сама копистика, уметност је стваралачко изграђивање. Она почива на реалној основи, али она је и нешто друго, нешто што упућује на нешто ново. Велики уметник је онај који успе да физички изрази духовну страну онога кога изображава. Уметност није украс него визуелно и духовно саопштавање невидљиве Божанске стварности која се манифестује у времену и простору. Уметник сведочи о историјским догађајима објављујући васкрсење уметности и наду у Царство Божије.

\section{Икона и прототип}

У православној теологији икона има значење нечега што онтолошки спаја две реалности. Икона није слика, копија нечега, већ је бићевно везана за прототип, што значи да је прототип присутан у икони. Учествовање у икони јесте учествовање у самом прототипу. Икона је личносног карактера, тј. светост коју икона има не потиче из њене природе већ из односа који има са личношћу.

Тема о значају иконе и прототипа у Цркви узела је простора у савременој теологији и, од појаве о. Георгија Флоровског и Митрополита Јована Зизјуласа, богословска мисао окренула се свом аутентичном онтолошком и есхатолошком карактеру. У теологији, икона као појам се онтолошки везује за есхатон. Митрополит Јован Зизјулас у својој теологији јасно истиче: ,,икону никако не треба схватити као нешто што нема онтолош- 
ке везе са стварношћу. Свети оци су јасно разликовали икону од типа. Док је тип поистовећиван са историјским догађајима, икона је увек указивала на догађаје везане за будућност". ${ }^{1}$ Из-

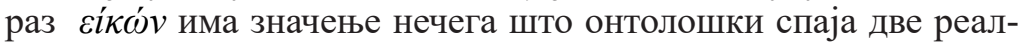
ности. Икона није слика, копија нечега, већ је бићевно везана за прототип, што значи да је прототип присутан у икони. Учествовање у икони јесте учествовање у самом прототипу. ${ }^{2}$ Битно је нагласити да је икона личносног карактера, тј. светост коју икона има не потиче из њене природе већ из односа који има са личношћу. На пример, човек је синоним за икону Божију. Човек је призван да као бивствујуће које има тај непроценљиви и свети дар ступи у потпуну заједницу са Богом и уподоби се егзистенцији у заједници слободе и љубави. Из тог разлога уметност је највиши израз човекове креативности. Док ствара уметничко дело човек одбацује реални свет и ствара свој нови свет. Чак се труди да се ослободи и датости материјала помоћу којег ствара. Уметност није пука копија реалности или њених својстава, она је одбацивање дате реалности и стварање нове. Зато је само човек привилегован да се бави уметношћу. На исти начин поступа и човек који жели да се уподоби Божијем начину постојања и постане савршена Личност. Он одбацује постојање као датост, одбацује своју биолошку ипостас и рађа се поново у слободи примајући свет као пројекцију сопствене воље. То је чин Крштења. Рађајући се изнова Духом Светим и примајући творевину у слободи, човек је узноси Богу и остварује њен пуни и прави смисао. Како бисмо сватили однос између иконе и прототипа требамо знати да ,појам иконе не умањује реалност откривења и виђења истине, већ се указује на отворен простор и начин личног односа и општења са јављеним у Христу личним Богом, што већ јесте Царство Божије, већ јављено и присутно, али још не сасвим 'у сили' и 'у пуноћи'.”’

\footnotetext{
${ }^{1}$ Јован Зизиулас, „Символизам и реализам у Православном богослужењу”, Саборност 1-4, 2001: 22.

${ }^{2}$ Никос А. Мацукас, Свет, човек, заједница: по Светоме Максиму Исповеднику (Нови Сад: Беседа, 2007), 250- 259.

${ }^{3}$ Атанасије Јевтић, „Есхатолошки карактер Цркве”, у О Цркви и Литургији,
} 


\section{Икона и подобије}

Човек постаје слободно биће једино и искључиво у заједници са Богом који је савршена и слободна личност. Човек je, баш зато, човек што има могућност да искорачи из света нужности и да се уподоби Божијој егзистенцији. ${ }^{4}$ То значи израз по образу, док би подобије било коначно остварење те савршене егзистенције. Св. Григорије Ниски, који се посебно бавио овим проблемом, као и св. Максим Исповедник, сматра да је „икона Божја у човеку слобода". 5 Проблем разлике између иконе и подобија решава се објашњењем појма иконе код св. Максима Исповедника који, следујући св. Григорију Ниском, као и теологији других кападокијских отаца, поистовећује појам иконе са слободом човека. Он истовремено показује да се истинска слобода човека управо садржи у начину постојања који је подобан Божјем. ${ }^{6}$ О самом квалитету живота говори нам и велики писац Ф. М. Достојевски: „тајна човековог живота није у томе да само живи, већ у томе зашто живи". Човек као икона Бога представља личност у својој потенцији (креативности), односно могућност да себе оствари као личност и превазиђе сопствену природу: „Слика припада категорији природе, а подобије категорији личности и запечаћује људско савршенство. Личност се формира током напорне борбе која за циљ има уздизање људске природе, или боље рећи њено

ур. Атанасије Јевтић (Врњачка Бања: Братство Св. Симеона Мироточивог, Требиње: Манастир Тврдош, 2007), 103.

${ }^{4}$ Изнети став бисмо могли да поткрепимо мислима солунског проф. Н. Мацукаса из његове књиге „Свет, човек, заједница”, који говорећи о стварању света каже да: „Чин стварања света не представља само појављивање саздане стварности из ништавила, већ истовремено сачињава и карику која сва бића и целокупну творевину повезује са Богом. То је најузвишенија тајна, која се човеку нуди као јединствено полазиште са којег он треба да започне своје прегнуће и да, пронашавши свога Творца, оствари властиту пуноћу.” Мацукас, Свет, човек, заједнииа: по Светоме Максиму Исповеднику, 45.

${ }^{5}$ Игнатије Мидић, „Човек као икона и подобије Божије: хришћанско схватање човека", Луча: часопис за филозофију, социологију и друштвени живот, 1984: 86-87.

${ }^{6}$ Ibid., 21. 
превазилажење".7 Формирање личности значи преображај покрета у енергију, природне воље у гномичку (личну) вољу, слике у подобије. Друкчије формулисано, оно значи ,уздизање човека у област божанског и његов дијалог с Богом лицем к лицу. На тај се начин испуњава крајњи циљ његовог стварања који је да славослови Божанство и да буде учесник Божанске славе и светлости". 8

Св. Максим објашњава однос иконе и подобија говорићи да је „човек икона Божија, тј. налик је Богу, због тога што је слободан у свом постојању у односу на природу". ${ }^{9}$ Будући да је човек икона Божија, то значи да је човечија природа створена као мирна, небунтовна и чврсто везана свезом љубави како са Богом, тако и са самом собом.

Икона Божија у човеку је оно што нас чини личностима и што нам даје одлику да можемо лично остварити заједницу (комуницирати) са Богом, да можемо живети у заједници са Њим и да га можемо знати. Само је Бог нестворен и бесмртан, али је обдарио човека могућношћу бесмртности. Зависно од човечије слободе (избора), он може живети вечно у заједници са Богом, а може одлучити и да не живи. Човеку је дата власт над природом. То потпуно можемо разумети, само ако посматрамо Христов живот и животе светитеља, који су своје животе дали за другог. Жртвујући себе другима испунили су заповест Божију да љубе ближњег свог као самог себе. Мученичка љубав је икона љубави Христове. Примери Светих нам показују дубоку есхатолошку припадност Христу и Царству Божијем. Христос је ради спасења целога људског рода сишао с неба на земљу, да спасе све људе из неограниченог милосрђа и неизмерне љубави. ${ }^{10}$ У лицу свога Јединороднога

\footnotetext{
7 Панајотис Христу, Тајна Бога, Тајна човека (Београд: Хиландарски фонд Богословског факултета СПЦ, 1999), 136-137.

${ }^{8}$ Ibid., 137.

${ }^{9}$ Мидић, „Човек као икона и подобије Божије: хришћанско схватање човека”, 22.

10 Захваљујући Христовом Оваплоћењу и Васкрсењу, могуће је остварење човековог назначења, тј. обожења које се постиже у сједињењу са Христом. Атанасије Јевтић, „Из словесника православља: Стварање и назначење чове-
} 
Сина, Бог је постао Човек и понудио свим људима спасење. Из своје слободе и из љубави према нама Син Божији је постао човек да би направио највећи корак у остваривању заједнице са нама. Да би човек остварио заједницу с Богом, потребно је да оствари заједницу с људима. Бог се пројављује у свету, као што смо видели, у потпуности кроз Христа који је Син Божији, али и човек, а затим кроз чланове евхаристијске заједнице, као и кроз сваког човека, јер човек је икона Божија. ${ }^{11}$ На тај начин љубав према Богу има као последицу љубав према људима, а пре свега заједницу са члановима Евхаристије. Тачније, заједница слободе, љубави човека с Богом у Христу гради Цркву као заједницу људи, и то посебне врсте. Јер, Христос се пројављује у свету кроз људе који су везани за њега у Евхаристији. Основао је Цркву у којој ми можемо, ако хоћемо да на ту страну усмеримо своју љубав, да узвратимо на Божију љубав и да уђемо у вечну заједницу са Њим. ${ }^{12}$ За сада ту нам је Света Литургија у којој се најближе сједињујемо са Богом али ће та заједница бити још чвршћа и лепша када Христос поново дође и уведе нас у Царство Божије.

\section{Икона и Царство Божије}

Појам иконе (слике) од крајњег је значаја за православно богословље. Не мислим само на икону Христа или светитеља које целивамо у нашим Црквама, него уопште на појам „иконизма” (осликавања). Све је у православној Цркви „иконизам” (осликавање). ${ }^{13}$ Осим светих икона, иконизми су и радње, покрети и личности светог богослужења. Свети

ка", Богословље 1-2, 1991: 57-63.

${ }^{11}$ Бог је љубав, при чему љубав не представља само „морални однос, него подражавање божанског живота: она се не намеће споља као некаква присила или рецепт, него извире из самог живота. Свет је створен из љубави, бива спасен из љубави и пројављује се кроз њу". Никос Мацукас, Проблем зла (Крагујевац: Каленић, 2005).

${ }^{12}$ Радован Биговић, Од Свечовека до Богочовека: хришћанска философија владике Николаја Велимировића, (Београд: Друштво Рашка школа, 1998).

${ }^{13}$ Јован Зизијулас, „Обожење светих као икона Царства Божијег“, Видослов: Саборник Епархије захумско-хериеговачке, 2000: 17-28. 
Максим све то назима „иконе” (слике), као и све оно што се дешавало и дешава у историјском животу Цркве. Све је слика будућих ствари, које ће и сачињавати истину оних иконизованих (ствари) у историји. Истина се, према томе, налази у будућности, у Царству Божијем. ${ }^{14}$

Хришћани верују у Божије обећање да ће се остварити Царство Божије на земљи. Читав живот нас, хришћана је испуњен том вером и надом. Храм где се сабирамо на Литургију грађен је тако да наликује на будуће Царство Божије. Сваки пут када се служи Литургија, ми у ствари доживљавамо то Будуће Царство. Зато кажемо да је црква икона Царства Божијег. Делови цркве нам указују на Царство Божије. У олтару, најсветијем делу цркве налази се часни престо, ту свештеници и ђакони на челу са епископом приносе дарове, хлеб и вино. Затим, постоји део где стоји верни народ. Тај део се назива наос или лађа цркве, због тога што црква представља лађу која нас носи у сусрет Господу Христу.

Свети Максим Исповедник нам однос између Иконе и Царства Божијег преноси на следећи начин: „догађаји Старог Завета представљају сенку, Новога Завета икону, а истина је стање будућег века." (PG 4, 137). На самом почетку опажамо да насупрот божанском откривењу у „сенци” кроз догађаје које смо имали у Старом Завету, имамо „икону”, која своје постојање дугује такође историјским догађајима који припадају новозаветној историји Божијег промисла о спасењу човека и света. Даље, судећи према исказу Светог Максима, истина творевине не налази се у прошлости, нити у некој паралелно (са) постојећој реалности (као нпр. духовни, идејни свет неоплатонизма ${ }^{15}$ већ да припада будућности која се, следствено, као таква још није догодила, односно будућности која представља стање ${ }^{16}$ чије се остварење тек очекује.

\footnotetext{
${ }^{14}$ Зизијулас, „,Обожење светих као икона Царства Божијег“, 17-28.

${ }^{15}$ Јован Зизиулас, „Евхаристија и Царство Божије”, Саборност 1-4, 2002: 23-87.

${ }^{16}$ Никола Лудовикос, Страхови личности и муке ероса: критичка разматрања постмодернистичке богословске онтологије (Цетиње: Манастир Рождества Пресвете Богородице-Свештени Манастир Цетињски, 2011), 14-57.
} 


\section{Онтологија историје}

\section{(Стари и Нови завет у односу на Есхатон)}

Између историје Старог и Новог завета постоји, као што је показано, онтолошка разлика управо у томе што је Нови завет нека врста поља преклапања, сједињавања и огледања будуће реалности у историји. Тачније, Нови завет је обожена историја, историја која је кренула ка свом правом циљу и која се приближава своме прототипу. Ако прецизно разграничимо појмове Есхатона, односно историје, можемо рећи да кључни појам који их раздваја јесте категорија начина постојања. У историји, човек постоји као биолошка ипостас, тј. постоји нужно и по природи. ${ }^{17}$

Онтолошка суштина света јесте небиће - свет је по себи ништа. Дакле, суштина створеног бића јесте небиће. Ово је, наизглед, парадоксална тврдња. Логички је бесмислено и нашем искуству незамисливо да суштина нечега што постоји буде непостојање, тј. негација сваког вида егзистенције. У томе се, међутим, састоји суштина појма стварања - то је увођење у егзистенцију нечега што пре момента стварања није нинакоји начин и ниуком облику постојало. То, такође, претпоставља и чињеницу да постоји друга реалност која ствара ову створену реалност. Коначно, то значи да је једини начин да створена реалност постоји тај да свој идентитет изнесе ван себе, пошто је по себи она небиће. Дакле, начин постојања створене реалности мора да буде у односу, у Другом. Затварање створеног бића у себе значи његово изумирање, ишчезавање и повратак у небиће, тј. апсолутно нестајање.

Идентитет творевине који је ван ње саме, тј. у Другом јесте други назив за личносно постојање. Насупрот томе, историја јесте управо зато историја што човек, и сва творевина са њим, нема личносно, већ природно постојање. Природа или суштина јесте оно што препознајемо као присуство постојања, мада је немогуће замислити огољену суштину - „не постоји

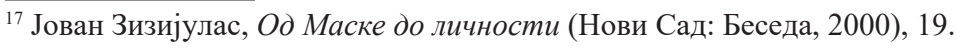


огољена суштина, вели свети Василије Велики". ${ }^{18}$ Не можемо замислити људску суштину без конкретних људи, нити суштину света без конкретних бивствујућих. Природа је оно што је опште (заједничко) и нужно. Две су битне последице створене природе - творевина је смртна и неслободна. О смртности творевине већ је било речи. Друга последица је неслобода. Творевина постоји нужно - тј. не зато што је желела да постоји, већ зато што јој је постојање дато. Њеном постојању претходи природа. Њој је егзистенција додељена и, што је најважније, окована је сопственом суштином. Другим речима оно што ми јесмо, целокупна наша природа и само постојање јесте датост за нас. Могућност избора између варијаната није слобода већ само илузија слободе, будући да су варијанте датости, а ,сама датост негира слободу". ${ }^{19}$ Сходно овоме, постати слободан значи одбацити биолошку ипостас, егзистенцију по природи и потпуно се ослободити свих датости, а најпре саме датости живота. Ово је мислиоце наводило да нихилизам виде као излаз из стања нужности. Један од најуспелијих литерарних оваплоћења ове идеје јесте Кириловљева мисао о самоуништењу из дела ,Зли дуси". ${ }^{20}$ Док год човек постоји, каже Кирилов, он је роб, несавршено биће јер је неслободан. Оног тренутка када реши да одузме себи егзистенцију ослобађа се датости живота и постаје слободан. Кирилов, као атеиста, изједначава човека самоубицу са Богом. Оног тренутка када одузме себи живот и реши се датости, вели Кирилов, човек престаје бити човек и постаје Бог. Оно што је најбитнији закључак у свему овоме јесте тај да разлика између човека и Бога јесте у слободи. Кирилов је један од најгенијалнијих ликова у светској књижевности јер увиђа најважнију онтолошку чињеницу - Бог је слободно биће, а слобода је божански начин постојања, односно синоним за савршену егзистенцију. Разлика, дакле, између створеног и нествореног бића јесте у категорији слободе - Бог

\footnotetext{
${ }_{18}^{18}$ Јован Зизјулас, Догматске теме (Нови Сад: Беседа, 2001), 199.

${ }^{19}$ Игнатије Мидић, Сећање на будућност (Пожаревац: Одбор за просвету и културу епархије браничевске, 2009), 109.

${ }^{20}$ Фјодор Михаилович Достојевски, Зли дуси (Београд: Рад, 1981).
} 
је слободан, а свет не. „Божије стварање света ни из чега подразумева да Бог постоји независно од постојања света". ${ }^{21}$ Коначно, оно што човека чини иконом Божијом и што налазимо најпре ког Григорија Нисијског, а онда и код Максима Исповедника јесте дефинисање слободе као онога што чини човека иконом Божијом.

\section{Онтологија Есхатона као онтологија слободе}

Уколико бисмо слободу избацили из Божијег промисла о свету читава историја као пут спасења изгубила би смисао. Целокупна повест спасења дешава се управо зато да би човек задобио божански начин постојања, да би постао слободан. Човек је створен, што значи да је смртан, али Бог није желео да човека на силу учини бесмртним, да му обезбеди трајно постојање без његове сагласности. Смисао је у томе што онда човек не би био човек, не би био икона Божија, не био имао ни свест о себи и свом постојању. Требало је да човек постане прави и потпуни човек, икона свога Творца, биће које постоји зато што то само жели и биће које креира егзистенцију. „Човек је требало да пронађе своје самоиспуњење у божанској доброти захваљујући сопственој промишљеној одлуци". ${ }^{22}$ Највећа радост и смисао човековог живота састоји се у сазнању да постоји и то као слободно биће. Без слободе као дара Божијег то сазнање и самосвест о сопственој егзистенцији и њеном смислу били би немогући. Оригиналност и значај богословља светог Максима јесте у глорификацији слободе, у повезивању човековог ума са слободном вољом. За разлику од јелинских филозофа који признају ум човеков за његов највреднији део, али немају идеју слободе, свети Максим уводи појам обоженог ума, тј. ума који је слободан, који напредује од образа ка подобију; „овај нагласак на рационалној способности душе као примарном одразу карактера човековог образа код Максима често уравнотежује са сличним нагласком на људској слобо-

\footnotetext{
${ }^{21}$ Мидић, Сећање на будућност, 114.

22 Ларс Тунберг, Микрокосмос и посредник - теолошка антропологија светог Максима Исповедника (Београд - Шибеник: Истина, 2008), 169-170.
} 
ди". ${ }^{23}$ Одузети човечанству слободу, а дати му заузврат сва могућа блага значи уништити човека. ${ }^{24}$ Најдрагоценији дар који човек има јесте његова слобода. Она је њему дата у заметку, као могућност коју треба да развије до пуноће. Развити себе до потпуне слободе значи заменити биолошку ипостас еклисијалном, односно постојати као Личност.

Личност сваког човека чини непоновљивим јер се идентификује у односу на Другог, тј. идентифукује се на основу љубави (заједнице), а љубав (заједница) јесте слобода као начин постојања. Уместо нихилизма као сваке негације бића и одговора на датост живота, постоји други богооткривен излаз из датости, а то је ново рођење за нову егзистенцију на начин заједнице. Та је егзистенција слободна будући да се човек поново рађа зато што то сам жели и пројављује своје постојање кроз однос са Богом смештајући у тај однос свој идентитет. Тако природа створеног бића више није онтолошки ослонац човека, она није ипостас, већ личност постаје ипостас. Такво, личносно тј. слободно постојање јесте есхатолошко постојање. Зато Есхатон, пре свега, треба посматрати као реалност остварене слободе. При том треба нагласити да је у хришћанском схватању слобода онтолошка категорија, и то фундаментална. „Онтолошка слобода, за разлику од етичке, подразумева да је постојање човека вечно и да је израз његове воље". ${ }^{25}$ Онтологију Есхатона можемо осветлити са више страна, али је, чини ce, изједначавање есхатолошког начина постојања и слободе најважнији моменат.

\section{Есхатон - стање Истине}

Есхатон, дакле, опитујемо већ сада кроз деловање Цркве у историји. Царство Божије је циљ и узрок историје. Зашто свети Максим назива ово стање Истином? Свакодневна логика нам не би помогла. У нашем етичком погледу на свет истина

${ }^{23}$ Ibid., 169.

${ }^{24}$ Ово је централна идеја Поеме о великом инквизитору из романа „Браћа Карамазови" Ф. М. Достојевског.

${ }^{25}$ Мидић, Сећање на будућност, 109. 
и лаж су појмови који стоје равноправно један спрам другог и односе се на поклапање, односно непоклапање суда (исказа) са објективним стањем ствари. ${ }^{26}$ У онтолошком, тј. светоотачком предању ови појмови имају потпуно другачије значење - они се не тичу односа формалног исказа и реалног стања, већ се тичу самог стања, саме реалности. Истина се изједначава са бићем, постојањем, док је лаж одсуство постојања, тј. истине. Пуноћу бића има једино Есхатон, док се историја креће ка тој пуноћи. Есхатон је синоним за постојање - потпуно, право, непомућено, вечно постојање и зато се назива Истином. Историја, која је усмерена ка њему, која још није задобила пуноћу егзистенције је, стога, његово огледало, одраз, и то, у оној мери у којој је сам Есхатон присутан у историји. „Не треба да заборавимо чињеницу да нам је Есхатон већ откривен и то управо као Црква у њеној евхаристијској пројави". ${ }^{27}$

Есхатон се различито именује у црквеном предању, а свим тим именима заједничко је то да указују на суштину Царства Божијег као стања непомућене радости. То је ,ход из славе у славу" (Кор 3,18), динамички циљ тока времена у коме, коначно, заживљава преображена творевена. „Онтологија света задржаће своје тварне карактеристике, „пројектоваће” се у Есхатон, с тим што унутар ње неће бити процес попут пропадљивости, труљења, болести и смрти. Простор и време који контролишу човека и твар ће поседовати раздвојеност, растојање, удаљеност, поделу, категорије пре и после, отежалост, непробојност, својства која овде и сада носе у себи смрт. Есхатон је преображени свет, онакав каквим га је пожелео Бо$\Gamma "{ }^{28}$ Свети Максим на више места говори о Царству: „Чисто

${ }^{26}$ Исто тако се и добро и зло дефинишу етички, „на основу људске логике, или чак на основу некакве воље Божије тумачене увек према људској логици”. Јован Зизјулас, „Онтологија и етика у светлости христологије св. Максима", Саборност 1-4, 2003: 108.

27 Игнатије Мидић, „Црква као нови начин постојања човека и творевине (изнад морала и институције)", Луча: часопис за филозофију, сощчиологију и друштвени живот, 1984: 546.

${ }^{28}$ Игнатије Мидић, „Александар Михаиловић, Границе медицине и хришћанска антропологија", Саборност 1-4, 2004: 104-105. 
је Царство Божије нешто узвишеније од свег вековног, јер неисправно је за Царство Божије рећи да оно подлеже вековном и временитом. Оно је, верујемо, баштина спасених, њихово, по истинитом предању (Цркве), боравиште и место, циљ и крајње жељено (свег) што се креће. Достигну ли га (они што к Њему се крећу) задобиће покој од сваке кретње, јер нема више ни времена ни векова кроз које би (још) требало да прођу. После свега до пред Бога свему Вишњег ће стићи, Који је пре свега вековитог бивствујућег и Који (никако) не спада у вековиту природу." (Гностички стослови, 2. 86) ${ }^{29}$; на другом месту каже: „Царство је небеско, кажу неки, живљење достојно небеса; други, да је то равноангелско стање спасених; неки, да је образ божанске красоте (оних) који носе „икону небеског” (1. Кор $15,49)$. По мени, сва три уверења су исправна..." (Гностички стослови, 2. 93). ${ }^{30}$

Нарочито су значајна нека одређења која налазимо у Седмој амбигви, која донекле осветљавају начин постојања у Царству Божијем. Навешћемо та места: „Неће, дакле, тада бити ничега што ће се налазити изван Бога, нити ће се што чинити да је насупрот Богу да би изазвало нечију жељу да тежи ка њему. Све ће (Бог) садржати у себи, све што је словесно и све чулно по својој неизрецивој пројави и својим присуством;..." 31 ; „Тада ћемо сазнати и суштину постојања (свих) бића, тј. шта су, којим начином (постоје) и ради којег циља постоје и, по мом мишљењу, нећемо више желети да се крећемо ни ка чему”32, „Њега неће сачињавати ваздух кога удишемо и издишемо, нити крв која протиче и истиче из јетре, већ Бог у Коме сви учествују (заједничаре) и који (Бог) ће на начин (односа) душе са телом постати души (живот), а кроз душу и тело; како то Он зна"33; ,Због тога су правилно назвали овакво стање

\footnotetext{
${ }^{29}$ Мидић, „Црква као нови начин постојања човека и творевине (изнад морала и институције)", 229.

${ }^{30}$ Ibid., 231.

${ }^{31}$ Ibid., 265.

${ }^{32}$ Ibid., 267.

${ }^{33}$ Ibid., 273.
} 
уживањем, страшћу, радошћу, које је састављено од божанског разумевања и оног што му следи, уживање у мудрости". ${ }^{34}$

Из свих ових навода можемо извући неколико закључака о Есхатону:

Есхатон је крајњи узрок, односно циљ историје;

То је стање планирано од Бога као начин постојања света;

То је стање пуноће бића, постојање без смрти и њених последица;

Есхатон је догађај будућности и истовремено је као икона присутан у садашњости;

У Есхатону постојаће свет као Тело Христово, све ће бити сједињено у Богу.

Простор и време, као и целокупна творевина и људска природа биће преображени и постојаће по благодати.

Оно што је код светог Максима ${ }^{35}$ значајно, у контексту доба у коме је живео, јесте уношење временске димензије у биће; сам језик , је темпоралан - то је језик континуитета и узастопности који одлично развија ,драму откривења”. ${ }^{36}$ Битна је, дакле, чињеница да Есхатон не сапостоји историји као паралелни ентитет, нити јој „претпостоји, већ да ће се остварити на крају историје"37, са другим Христовим доласком и општим васкрсењем мртвих. Реч је о стању Будућег века, о будућности која усмерава историјско време чинећи га својим одразом.

\footnotetext{
${ }^{34}$ Ibid., 273.

${ }^{35}$ Можда Максимово постигнуће није коначно: „Теологија не сме да буде ограничена само на понављање прошлости. Али, она мора бити надахнута визијама као што је визија светог Максима, како би наставила да буде сведочење, исповедање, проповед истога Христа и исте вере, која је једном за свагда предана светима”. Видети: Димитриос Батрелос, Византијски Христос (Крагујевац: Каленић, 2008), 214.

${ }^{36}$ Пол М. Блауерс, „Испуњена есхатологија по светом Максиму Исповеднику, Ad Thalassium 22", Луча: часопис за филозофију, социологију и друштвени живот, 1984: 504.

${ }^{37}$ Игнатије Мидић, Биће као есхатолошка заједница (Пожаревац, Одбор за просвету и културу Епархије браничевске, 2008), 210.
} 


\section{Те́’ло丂 и Есхатон}

Још као што су философи пре Христа доказивали, овај свет као збир контигентних бића не може постојати сам по себи и сам за себе, тј. контигентна бића нису сама себи могла дати постојање. Биће које је у стању кретања и промене није само себе покренуло, јер да јесте, оно само се не би мењало, било би свагда себи једнако, исто, хомогено. На овај начин је Аристотел доказао постојање Бога као „непокретног покретача”; наиме, мора постојати узрок који је све ставио у покрет, а који се, опет, не креће. Тај узрок, Аристотел је назвао Богом, мада је, наравно његов појам Бога далеко од оног појма Бога који смо ми стекли откровењем. Ипак, постоји нешто у Аристотеловој метафизици што је веома необично за античку философију, али и за философију уопште. Философија трага за узрочно-последичним везама, како ју је дефинисао Лок ${ }^{38}$, и, по правилу, узрок је везан за прошлост. Тако је и у нашем искуству - узрок временски претходи последици. Крајњи узрок свих узрока, последњи узрок мора, дакле, стајати временски пре свих својих последица, тј. пре читавог узрочно-последичног низа који је покренут. Ако трагамо за узроком, морамо завирити у прошлост. И многи хришћани, погрешно уносећи платонизам у хришћанство, заменили су есхатон неком визијом раја која је постојала пре Адамовог пада, чак и пре стварања материјалног света. Тако је за њих идеално стање било на почетку. У оригенистичкој интерпретацији то идално стање било је пре стварања, тј. пре пада душа у материјалну реалност. Слично је код Платона - циљ постојања је повратак душе у стање савршенства пре пада. Дакле, стање из прошлости је идеал коме тежимо и узрок који нас покреће. То није, наравно, хришћанска концепција, али јесте природна, логички лако објашњива и популарна.

Аристотел, као што је поменуто, први пут, и то пре хришћанства, објашњава узрок на другачији начин него што

${ }_{38}$ Фредерик Коплстон, Историја философије, Британски емпиризам (Београд: БИГЗ, 1991). 
то чине остали. У његовом систему узрок има више аспеката ${ }^{39}$, а најважнији узрок је финални. Финални узрок представља сврху одређене појединачне ствари, али и бића као целине. Он је развој предмета из потенцијалности у актуалност. Тє́ $\lambda$ о тј. сврха предмета временски долази после првобитне појаве предмета. На пример, жир постоји као бивствујуће које тежи да постане храст. Храст је сврха жира и његово истинско стање. Жир је потенцијални храст. ${ }^{40}$ Актуалност настаје после фазе потенцијалности. Телос је оно што омогућује одржавање идентитета и јединства упркос сталној промени и кретању. Зато тело, мењајући се, не само да не губи свој идентитет, већ му се приближава. Сама по себи, посматрано изоловано од Аристотелове филозофије, ова теорија може изгледати као антиципација учења о историји и Есхатону и може нам показати да није тако тешко замислити да узрок не мора временски да претходи последици, већ да може доћи после ње. Истовремено, показује нам да кретање и променљивост нису „непријатељи" бића и идентитета, већ да се могу уклопити у постојање не нарушавајући идентитет једног.

\section{Закључак}

Можемо закључити да је за онтологију мериторна чињеница да је историја икона Есхатона и да је Црква, на првом месту, есхатолошки догађај. То потврђује сама света литургија, апостолско и светоотачко предање. Занемаривање те чињенице води, на крају крајева, губитку Евхаристије, а то је једнако губитку хришћанства, будући да је оно догађај сабрања. Тек накнадно, из овог искуства извиру етичке и теоријске вредности. Етика не би смела да заузме примарно место и одвоји се од живота Цркве. Исто важи и за богословље и за све социјалне и практичне околности везане за живот савремених хришћана. Оно што је смисао сваке расправе о односу Есха-

${ }^{39}$ Постоје четири узрока: финални, делатни, материјални и формални. Видети: Фредерик Коплстон, Историја философије, том I, Грчка и Рим (Београд: БИГЗ, 1991).

${ }^{40}$ O теорији жира види: Džejms Hilman, Kod duše (Beograd: Fedon, 2010). 
тона и историје јесте свест о значају самог искустава које нам Бог дарује о будућем Царству. Свака богословска реч о Царству утемељена је на конкретном искуству тога Царства које имамо у Цркви. Ван тога искуства немогуће је схватити овај однос. „Да би постао православан, човек мора тренутно уронити у биће православља, започети православни живот - другог пута нема". ${ }^{41}$ Отуда, они који су се током векова одвајали од црквене заједнице, никада нису могли правилно да богословствују јер разумевање тајне спасења дар је Духа Светог, а не индивидуалног рационалног напора појединца. Протестантима и римокатолицима православни замерају „изгнање Бога у искуству неприступан круг". ${ }^{42}$ Можда и мало претерана оцена правосланих теолога да се „римокатолик или протестант може постати у радној соби”, тј. без опита, свакако показује да је православље препознатљиво по својој литургијској димензији међу хришћанским конфесијама. Поред свих невоља савременог живота и питања у савременој теологији, Исток је остао веран својој есхатолошко-еклисиолошкој суштини и то је оно што је гарант спасења и гарант онтолошког јединства Цркве. То је основа уједињења Истока и Запада.

Смисао целокупне икономије спасења јесте коначна победа над смрћу и остварење савршене егзистенције у Христу. Тај коначни циљ одржава саму историју у живом и динамичном току и даје смисао сваком догађају унутар ње. Без тога циља, тј. без Есхатона на њеном крају, историја би одавно пресахла и увела као нит откинута са извора живота. Зато је православна сотириологија, и целокупна теологија уопште, усмерена на онтологију Есхатона као кључни моменат. У делима светог Максима та оријентација је јасна - целокупна хришћанска етика обилато је поткрепљена развијеним и аргументованим онтолошким дискурсом. Коначно, сама онтологија јесте живот Цркве, опит заједничарења са Христом и тај опит увек је код православних био мерило и ауторитет истинитости.

${ }^{41}$ Karl Cristian Felmy, Die orthodohe Theologe der Gegenwart: Eine Einführung (Darmstadt: Wiss, Buchges, 1990).

${ }^{42}$ Ibid., 6. 


\section{Литература:}

Извори:

Migne, J. P., ed. Patrologia Graeca. Vols. 4. Paris 1857-1886.

Turnhout, Declerck J. H., ed. Corpvus Christianorvm, Series Graeca: Maximus Confessor. Quaestiones et dubia. Leuven 1982.

Преводи на српски језик:

Ђаковац, Александар, прев. „Одговори Таласију I-VI”. Caборност VIII, 2002: 13-21;

Зизјулас, Јован. Јединство Цркве у светој Евхаристији и у епископу у прва три века. Нови Сад: Беседа, 1997.

Зизјулас, Јован. Од маске до личности. Нови Сад: Беседа, 2000.

Зизјулас, Јован. Догматске теме. Нови Сад: Беседа, 2001.

Зизијулас, Јован. „Символизам и реализам у православном богослужењу”. Саборност 1-4, 2001: 13-35.

Зизјулас, Јован. „Онтологија и етика у светлости христологије св. Максима”. Саборност 1-4, 2003: 13-60.

Јевремовић, Петар, прев. Гностички стослови: Поглавља о теологији и икономији Оваплоћеног Сина Божијег. Београд: Библиотека часописа Источник, 1996.

Јевремовић, Петар, прев. „Одговори Таласију VIII, XIV, XLVI”. Источник 14/16, 1995: 5-6.

Јевтић, Атанасије. Патрологија, друга свеска. Источни очи и писии четвртог и петог века. Београд: Хришћанска мисао, 2004.

Јевтић, Атанасије, прир. Дела апостолских ученика. Врњци: Братство св. Симеона Мироточивог; Требиње: Манастир Тврдош, 2005.

Јевтић, Атанасије. Христос-Нова Пасха: Божанствена литургија: свештенослужење, причешће, заједница богочовечанског тела Христовог. Београд: Света Гора Атонска, Манастир Хиландар; Никшић: Манастир Острог; Требиње: Манастир Тврдош, 2007.

Коплстон, Фредерик. Историја философије. Том I, Грчка и Рим. Београд: БИГЗ, 1991. 
Коплстон, Фредерик. Историја философије: Британски емпиризам. Београд: БИГЗ, 1991.

Мацукас, Никас А. Проблем зла. Крагујевац: Манастир Каленић, 2005.

Мацускас, Никос А. Свет, човек, заједница - по светоме Максиму Исповеднику. Нови Сад: Беседа, 2007.

Мидић, Игнатије, прев. „Амбигва 7”. Беседа 2, 1992: 5-28.

Мидић, Игнатије. „Црква као нови начин постојања човека и творевине (изнад морала и институције)". Луча XXI - XXII: часопис за филозофију, сочиологију и друштвени живот, 2006: 546-559.

Мидић, Игнатије. Биће као есхатолошка заједнииа. Пожаревац: Одбор за просвету и културу епархије браничевске, 2008.

Мидић, Игнатије. Сећање на будућност. Пожаревац: Одбор за просвету и културу епархије браничевске, 2009.

Тунберг, Ларс. Микрокосмос и посредник - теолошка антропологија светог Максима Исповедника. Београд - Шибеник: Истина, 2008.

Тунберг, Ларс. Човек и космос - визија светог Максима Исповедника. Београд - Шибеник: Истина, 2008.

Felmy, Karl Cristian. Die orthodohe Theologe der Gegenwart: Eine Einführung. Darmstadt: Wiss, Buchges, 1990.

Hilman, Džejms. Kod duše. Beograd: Fedon, 2010. 
THE ONTOLOGICAL ICONIC CHARACTER OF THE KINGDOM OF GOD

Darko Stojanović, Academy of the Serbian Orthodox Church for Arts and Conservation, Belgrade e-mail: darkostoja@gmail.com

Summary: In recent years there has been a sort of 'rediscovery' of icons by Western Christians. There is an increasing awareness that the icon is not merely a work of art, but is also an aspect of diving revelation and of our communing with God in the Church. Thus the icon cannot be separated from Orthodox belief, prayer or liturgical life. To fully understand the icon, one must comprehend its organic unity: artistic, spiritual, theological. Quenot's analysis of various icons and their theological elements enables the readers to appreciate the various aspects of the icon more fully. There are currently many books written about icons, discussing either their historical context, describing their spiritual attraction, or simply showing their aesthetic beauty. The Icon is, however, an exceptional book in many ways.

Key words: Ontology, Icon, Kingdom of God, Orthodoxy christianity, Church art. 